О. В. БАШТА ${ }^{1}$, П. Л. НОСКО ${ }^{1}$, О. В. РАДЬКО ${ }^{2}$, О. В. ГЕРАСИМОВА A. О. БАШТА ${ }^{3}$

\author{
${ }^{1}$ Національний авіаційний університет, Украӥна \\ ${ }^{2}$ Національний університет оборони Украӥни імені І. Черняховського, Украйна \\ ${ }^{3}$ Нацональний університет харчових технологій, Украӥна
}

\title{
ДОСЛІДЖЕННЯ ВТРАТ ПОТУЖНОСТІ ВНАСЛІДОК ТЕРТЯ КОВЗАННЯ І КОЧЕННЯ В ЗУБЧАСТОМУ ЗАЧЕПЛЕННІ. ОГЛЯД
}

Проведено аналіз досліджень щзодо втрат потужності внаслідок тертя в зубчастих парах. Встановлено, що визначення ККД зубчастих передач застосовують три різних підходи: безпосереднє вимірювання втрат потужності реальної зубчастої передачі;контактно-динамічне моделювання на основі реальних фізичних прочесів; аналітичне моделювання прочесів тертя в зубчастій передачі на підставі емпіричної інформачії про тертя, отриманої на спечіальних машинах тертя. Встановлено, що величини сил тертя між сполученими зубиями значною мірою визначаються гідродинамічними (еластогідродінамічними) явищами в зоні контакту. Аналіз робіт показав, щуо контакт між поверхнями сполучених зубців характеризується великими деформаціями, високими контактними напруженнями і наявністю плівки мастильного матеріалу, яка 8 свою чергу характеризується його в'язкісними якостями. На сьогоднішній день вплив ковзання в напрямку лінії контакту зубиів на коефіцієнт тертя і умови змазування недостатньо вивчені. В опублікованих роботах наявні дві групи напіваналітичних моделей. Перша група авторів досліджувала ефективність прямозубих передач, припускаючи, щчо коефічієнт тертя постійний уздовж всієї поверхні контакту поверхонь тертя в будь-яких положеннях зубчастих коліс при їх обертанні. Проте вони мають ряд суттєвих недоліків. Прийнято, щуо коефіцієнт тертя постійний $i$ заздалегідь відомий для кожної точки дотику пари зубиів. Однак експериментальні дані для двох фрикиійних дисків показують, що в умовах комбінованого контакту ковзання / кочення коефіиієнт тертя не постійний $і$ на нього впливають безліч параметрів. Також изі моделі обмежувалися тільки прямозубими зубчастими колесами $і$ не враховували багато факторів, які вносять значне ускладнення моделей. Друга група напіваналітичних моделей може розглядатися, як поліпшення моделей першої групи з постійним коефіиієнтом тертя. На сьогоднішній день моделі другої групи потениійно більш точні, ніж моделі першої групи. Точність опису за допомогою иих моделей обмежена точністю використовуваних в них емпіричних формул. Ці емпіричні формули не носять загальний характер і часто є функцією певних типів мастила, діючих температур, швидкісних і навантажувальних меж, чистоти поверхонь випробовуваних зразків, які, можливо, відрізняються від аналогічних параметрів реальних зубчастих коліс.

Ключові слова: втрати потужності, коефіцієнт корисної дії, контактногідродинамічна теорія, напіваналітичні моделі, коефічієнт тертя.

Вступ. До втрат потужності, що залежать від переданого навантаження, відносяться втрати, що затрачуються на тертя ковзання і кочення в зубчастому зачепленні та підшипниках передачі. При відносно невеликих окружних швидкостях зубчастих передач саме ці втрати є домінуючими. Тенденція помірних окружних швидкостей при великих переданих навантаженнях зберігалася до середини двадцятого століття, що зумовило інтенсивні дослідження ефективності зуб- 
частих передач 3 точки зору цих втрат потужності протягом останніх 150 років [1]. Огляд більшості опублікованих досліджень по тертю і коефіцієнту корисної дії представлений в роботах [2].

Аналіз останніх досліджень і літератури. Встановлено, що величини сил тертя між сполученими зубцями значною мірою визначаються гідродинамічними (еластогідродінамічними) явищами в зоні контакту. Аналіз робіт А.І. Петрусевича [3, 4], А.Г. Ертеля, А.Н. Грубіна, Д.С. Кодніра [5], В.Н. Кудрявцева [6] , G.H. Benedict [3], R. Gohar [8] показав, що контакт між поверхнями сполучених зубців характеризується великими деформаціями, високими контактними напруженнями і наявністю плівки мастильного матеріалу, яка в свою чергу характеризується його в'язкісними якостями.

3 точки зору методики проведених досліджень ККД зубчастої передачі застосовують три різних підходи:

а) безпосереднє вимірювання втрат потужності в реальній зубчастій передачі або їі фізичній моделі;

б) емпірико-аналітичне моделювання зубчастої передачі з використанням попередньо заданих постійних коефіцієнтів або емпіричної інформації про коефіцієнти тертя;

в) аналітичне моделювання ефективності зубчастої передачі на підставі реальних фізичних процесів з використанням розрахунку коефіцієнта тертя за допомогою контактно гідродинамічної моделі.

Перша група експериментальних досліджень присвячена вимірюванню втрат потужності внаслідок тертя між зубцями зубчастої пари $[9,10,11,12,13,14]$.

Ряд інших дослідників намагалися застосувати результати експериментів по визначенню коефіцієнта тертя в елементах простої форми контакту (найчастіше два однакових гладких диска) до пари зубців зубчастих коліс. Експеримент и проводилися в умовах близьких до експлуатації реальних зубчастих передач [15, $16,17,18,19,20,21]$. У деяких з цих досліджень $[15,17,19,20]$ отримані добре відомі і широко застосовуються в наступних роботах по тертю емпіричні формули для визначення коефіцієнтів тертя.

Н.Ф. Кузьмін [22] дає наступну формулу:

$$
C_{f}=\frac{\frac{S}{U}}{q_{1}+q_{2} \cdot \frac{V_{s}}{U}+q_{3} \cdot\left(\frac{V_{s}}{U}\right)^{2}}+q_{4} \cdot\left(\frac{V_{s}}{U}\right)^{2},
$$

де $U$ - швидкість кочення поверхонь, м/с; $V_{s}$ - швидкість ковзання поверхонь, м/с; $q_{i}$ - параметри, отримані з експериментальних кривих.

Ю. А. Мішарін запропонував в діапазоні зміни коефіцієнта тертя $0.02<C_{f}<0,08$ аналогічну залежність, але 3 урахуванням кінематичної в'язкості мастильного матеріалу [23]:

$$
C_{f}=\frac{0,325}{\left(v_{0} \cdot U \cdot V_{s}\right)^{0,25}},
$$

де $v_{0}$ - кінематична в'язкість мастильного матеріалу, сСт.

H. Blok [25] критично оцінив результати, отримані Ю.А. Мішарін, зазначивши, що незначна зміна відносної $\mathrm{V}_{\mathrm{s}}$ робить формулу (2) ненадійною.

Більш помітну залежність коефіцієнта тертя від швидкостей ковзання і кочення отримали Benedict i Kelley [15]: 


$$
C_{f}=0,0127 \cdot \log _{10}\left|\frac{3,17 \cdot 10^{8} \cdot F_{n}}{\mu_{0} \cdot V_{s} \cdot U^{2}}\right|,
$$

де $\mu_{0}$ - динамічна в'язкість мастила, Па·с; $F_{n}$ - розподілена нормальне навантаження, фунт/дюйм; $U$ - швидкість кочення поверхонь, дюйм/с; $V_{s}-$ швидкість ковзання поверхонь, дюйм/с.

O'Donoghue i Cameron [21] запропонували іншу залежність з урахуванням геометрії поверхонь тертя:

$$
C_{f}=\frac{s+22}{35} \cdot \frac{0,6}{\mu^{1 / 8} \cdot V_{s}^{1 / 3} \cdot U^{1 / 6} \cdot \rho_{k}^{1 / 2}},
$$

де $s$ - шорсткість поверхонь тертя, мікродюйм; $\rho_{\mathrm{k}}-$ приведений радіус кривизни, дюйм.

O'Donoghue i Cameron [21] також провели порівняння результатів, отриманих Ю.А. Мішаріним [23], Crook [24], Sasaki i Watson за допомогою запропонованого ними критерію $\mu^{1 / 8} \cdot V_{s}^{1 / 3} \cdot U^{1 / 6} \cdot \rho_{k}^{1 / 2}$ і тільки результати Ю.А. Мішаріна [23] значно відрізнялися.

Вплив радіусів кривизни поверхонь тертя на коефіцієнт тертя відзначали також Kelley i Lemanski [26]:

$$
C_{f}=0,0099 \cdot \frac{1}{1-\frac{s}{45}} \cdot \log _{10}\left[\frac{50,8 \cdot F_{n}}{\mu_{0} \cdot V_{s} \cdot U^{2} \cdot\left(\rho_{p}+\rho_{g}\right)^{2}}\right],
$$

де $U$ - швидкість кочення поверхонь, м/с; $V_{s}$ - швидкість ковзання поверхонь, м/с; $F_{n}$ - розподілене нормальне навантаження, $\mathrm{H} ; \rho_{\mathrm{p}}$ - радіус кривизни зуба шестерні, м; $\rho_{\mathrm{a}}$ - радіус кривизни зуба шестерні, м.

$$
C_{f}=\frac{1}{0,8 \cdot v_{0}^{1 / 2} \cdot V_{s}+U \cdot \phi\left(P_{\max }, v_{0}\right)+13.4},
$$

де $\phi\left(P_{\max }, v_{0}\right)=0,47-0,13 \cdot 10^{-4} \cdot P_{\max }-0,4 \cdot 10^{-3} \cdot v_{0}$ - параметр, що залежить

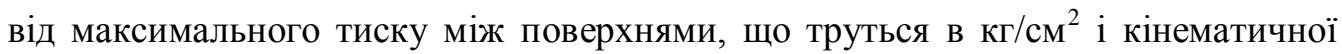
в'язкості.

Наведені вище емпіричні залежності констатують, що коефіцієнт тертя $є$ функцією численних параметрів, таких як швидкості кочення і ковзання, радіуси кривизни поверхонь тертя, навантаження або контактного тиску, шорсткості поверхні і в'язкості мастильного матеріалу. Однак швидкості ковзання в емпіричних формулах спрямовані перпендикулярно контактній лінії і розподілені рівномірно уздовж лінії контакту. У розглянутих вище експериментальних роботах були відсутні дослідження переміщення випробовуваних фрикційних дисків в осьовому напрямку. Отже, формули (1 - 6) не можуть бути застосовані для косозубих, черв'ячних і гіпоїдних передач. Для таких передач радіус кривизни змінюється уздовж лінії контакту і з'являється складова швидкості ковзання уздовж лінії контакту.

На сьогоднішній день вплив ковзання в напрямку лінії контакту зубців на коефіцієнт тертя і умови змазування недостатньо вивчені. Група експериментальних дослідників [27, 28, 18, 29] спробувала виявити зв'язок між умовами контакту в експериментах з парою фрикційних дисків і реальної зубчастої парою. 
Hirano [28] вивчав вплив кута між напрямками швидкості ковзання і лінії фрикційного контакту на коефіцієнт тертя. Виявилося, що ковзання уздовж лінії контакту збільшує коефіцієнт тертя. Höhn [18] і Tan [29] в двох незалежних одна від одної дослідженнях черв'ячних передач прийшли до висновку, що збільшення ковзання уздовж лінії контакту, при постійних значеннях швидкостей ковзання і кочення нормальних до лінії контакту, збільшує коефіцієнт тертя.

Напіваналітичні моделі в опублікованих роботах можна розділити на дві групи. Перша група авторів робіт [30, 31] досліджувала ефективність прямозубих передач, припускаючи, що коефіцієнт тертя постійний уздовж всієї поверхні контакту поверхонь тертя в будь-яких положеннях зубчастих коліс при їх обертанні.

Дотична сила тертя вздовж напрямку ковзання була розрахована в залежності від заздалегідь обраного відомого коефіцієнта тертя і геометричних і кінематичних параметрів прямозубих зубчастих коліс. Коефіцієнт корисної дії був розрахований по зменшенню моменту, переданого на ведене колесо. Ці моделі, будучи вельми корисними, для якісного розуміння ролі геометрії прямозубих зубчастих коліс на коефіцієнт корисної дії передачі, мають ряд суттєвих недоліків. Перший недолік криється в способі визначення коефіцієнта тертя. Прийнято, що він постійний і заздалегідь відомий для кожної точки дотику пари зубців. Однак, як зазначалося вище, експериментальні дані для двох фрикційних дисків [9, 10, $11,12,13,14]$ показують, що в умовах комбінованого контакту ковзання / кочення коефіцієнт тертя не постійний і на нього впливають безліч параметрів. Другий недолік полягає в тому, що моделі обмежувалися тільки прямозубими зубчастими колесами і не враховували багато факторів (згинні та контактні деформації зубців, коригування профілю зубців, неточність виготовлення зубчастих коліс та ін.), які вносять значне ускладнення моделей.

Друга група напіваналітичних моделей $[32,33,34,18]$ може розглядатися, як поліпшення моделей першої групи з постійним коефіцієнтом тертя. Ці моделі засновані на опублікованих експериментальних формулах, як, наприклад, наведених вище і описують ефективність прямозубих $[32,33]$ і косозубих [34] передач. На сьогоднішній день моделі другої групи потенційно більш точні, ніж моделі першої групи. Точність опису за допомогою цих моделей обмежена точністю використовуваних в них емпіричних формул. Ці емпіричні формули не носять загальний характер і часто є функцією певних типів мастила, діючих температур, швидкісних і навантажувальних меж, чистоти поверхонь випробовуваних зразків, які, можливо, відрізняються від аналогічних параметрів реальних зубчастих коліс.

Існує велика кількість моделей [35, 24, 37, 2, 38, 39, 36 та ін.], що описують ефективність зубчастих передач 3 використанням теорії контактногідродинамічної мастила, розробленої в 1940-1945 р.p . А.І. Петрусевичем, А.М. Ертслем і А.Н. Грубіним.

Dowson i Higginson [40] і Мартін [2] в припущенні про гладкі контактуючі поверхні зубців прямозубих передач розрахували миттєвий коефіцієнт тертя, спровокованого дотичним напруженням масляної плівки на гладкій поверхні контактно гідродинамічної моделі.

Adkins i Radzimovsky [35] розробили модель ефективності для легко навантажених циліндричних зубчастих коліс при гідродинамічними умовах змащування, припустивши, що зубці абсолютно жорсткі.

Саймон [38] запропонував модель розрахунку ефективності, використовуючи контактно-гідродинамічну теорію мастила в припущенні про точковий контакт в 
крупномодульних прямозубих передачах з гладкими поверхнями зубців. Він розглядав пружні деформації поверхонь зубців внаслідок тиску на них мастила.

Larsson [39] провів контактно-гідродинамічний аналіз евольвентних прямозубих передач з гладкими поверхнями зубців. У цьому аналізі, плівка мастила повної товщини була розглянута в ізотермічних умовах за допомогою моделі неньютоновской рідини. Зубці коліс передбачалися абсолютно жорсткими.

Wang [37] проаналізував змазування евольвентної прямозубої передачі методами контактно-гідродинамічної теорії за допомогою моделі ньютонівської рідини. У цій моделі, зубці колеса також передбачалися жорсткими і гладкими. Передбачалося, що навантаження передавалася однією парою зубців, або двома парами зубців при ії трапецієподібному розподілі.

Wu i Cheng [35] розробили модель тертя в прямозубої передачі, засновану на теорії контактно-гідродинамічного змішаного змащення. Шорсткість поверхні моделювалася таким чином, що всі мікронерівності мають той же радіус кривизни, а їх висоти мають Гаусовий розподіл. У цьому дослідженні була використана емпірична формула тертя, запропонована Goksem i Hargreaves [35] для ізотермічних контактів тертя.

Michalidis [36] також враховував вплив шорсткості на коефіцієнт тертя. Чисельно заданий шорсткий профіль був вхідним параметром в розробленій моделі. Матеріали зубчастих коліс передбачалися абсолютно пружними. Були розглянуті також теплообмін і неньютонівська поведінка мастила.

Літературні джерела, що досліджують ефективність косозубих передач вкрай нечисленні. Роботи Akin [41], Wellauer i Holloway представили методику розрахунку на базі контактно-гідродинамічної теорії мастила, товщини плівки мастила уздовж лінії зачеплення косозубої передачі, використовуючи формулу товщини плівки, запропоновану Dowson i Higginson [40].

Chittenden [42] представив узагальнений аналіз контактно-гідродинамічного завдання гладких поверхонь зубців при ізотермічних умовах.

Haizuka [43] експериментально вивчав вплив кута нахилу зубців на втрати потужності внаслідок тертя в косозубих передачах і прийшов до висновку, що втрати потужності збільшуються з ростом кута нахилу зубців.

Для розрахунку коефіцієнта корисної дії Бекінгем [44] запропонував наближену формулу для втрат потужності в гіпоїдних передачах, яка є спільною для розрахунку втрат в спіральних конічних зубчастих і черв'ячних передачах.

Coleman [45] використовував просту формулу з дуже обмеженим рядом параметрів, щоб обчислити коефіцієнт корисної дії конічних і гіпоїдних передач. У більш пізній роботі він запропонував цікаву формулу для конічних і гіпоїдних передач, що включає формулу для визначення коефіцієнта тертя, який є функцією лише швидкості і шорсткості поверхні. Контактно-гідродинамічне завдання в застосуванні до коригованих гіпоїдних передач вирішував Simon [38], використовуючи модель точкового контакту.

Jia [46] проаналізував 3 точки зору контактно-гідродинамічної теорії мастила гіпоїдні передачі, визначаючи товщину масляного шару і розподіл тиску в контакті при ізотермічних умовах.

Проведений аналіз досліджень щодо втрат потужності внаслідок тертя в зубчастих парах дозволяє зробити висновок про доцільність в подальшому використання емпірично-аналітичної моделі тертя ковзання з урахуванням різних умов, режимів навантаження та експлуатації, при побудові якої розглядати на- 
ступні випадки: коефіцієнт тертя ковзання є сталим, але відмінним для двопарного і однопарного зачеплень $f_{1} \neq f_{2}=$ const; коефіцієнт тертя ковзання $є$ змінним в залежності від відносної швидкості спряжених поверхонь зубців, але однаковий для двопарного і однопарного зачеплень $f_{1}=f_{2}=f=\operatorname{var}$ (емпіричні залежності коефіцієнту тертя ковзання від швидкостей ковзання та кочення, що наведені в технічних довідниках). Це дозволить з мінімальними витратами обчислювальних зусиль кількісно оцінювати втрати потужності внаслідок тертя ковзання та кочення в зубчастому зачепленні та проводити аналіз впливу геометричних параметрів, якостей змащувального матеріалу та умов експлуатації зубчастої передачі.

Висновки. 1. Дослідження тертя в зубчастому зачепленні можна умовно розділити на три напрямки: безпосереднє вимірювання втрат потужності реальної зубчастої передачі; контактно-динамічне моделювання на основі реальних фізичних процесів; аналітичне моделювання процесів тертя в зубчастій передачі на підставі емпіричної інформації про тертя, отриманої на спеціальних машинах тертя.

2. Використання емпірично-аналітичної моделі тертя ковзання з урахуванням різних умов, режимів навантаження та експлуатації дозволить проводити аналіз впливу геометричних параметрів, якостей змащувального матеріалу та умов експлуатації зубчастої передачі на втрати потужності внаслідок тертя ковзання та кочення в зубчастому зачепленні.

\section{Список літератури}

1. Reuleaux F. Friction in tooth gearing / Transactions of the ASME. - 1886. - Vol. VIII. - P. 45-85.

2. Martin K.F. A review of friction predictions in gear teeth / Wear. - 1978. - № 49. - P. 201-238.

3. Petrusevych A.Y. Kontaktnaia prochnost detalei mashyn /- M.: Mashynostroenye, 1970. - $64 \mathrm{~s}$.

4. Petrusevych A.Y. Uproshchennыi metod reshenyia kontaktno-hydrodynamycheskykh zadach / Mashynovedenye. -1971.-№6.-S. 72-76.

5. Kodnyr D.H. Kontaktna hydrodynamyka smazky detalei mashyn / - M.: Mashynostroenye, 1976. - $304 \mathrm{~s}$.

6. Kudriavtsev V.N. Raschet y proektyrovanye zubchatukh reduktorov: Spravochnyk / V.N. Kudriavtsev, Y. S. Kuzmyn, A.L. Fylypenkov; Pod obshch, red. V.N. Kudriavtseva. SPb.: Polytekhnyka, 1993. - 448 s.

7. Benedict G.H. Instantaneous coefficients of gear tooth friction. / G.H. Benedict, B.W. Kelley // Tribology transactions. - 1961. - Vol. 4. - P. 594.

8. Gohar R. Oil film thickness and rolling friction in elastohydrodynamic point contact / J. Lubrication technology. - 1971. - №93 (3)-P.371.

9. Changenet $\mathrm{C}$. Power losses and heat exchange in reduction gears: numerical and experimental results. / C. Changenet, M. Pasquier. // VDI -Berichte. - 2002. -№ 1665. - P. 603-613.

10. Hori K. Determination of the tooth surface friction coefficient of a pair of mating gears based on the distribution along the tooth profile precisely measured with the gravity pendulum method / K. Hori, I. Hayashi. N Iwatsuki // Proceedings of DETC'00/PTG-14371. Baltimore. Maryland. 10-13 September. 2000.

11. Ikejo K. Power loss of spur gear drive lubricated with traction oil / K. Ikcjo, K. Nagamura // DETC'03/PTG, Chicago, Illinois, 2003.

12. Mizutani H. Power loss of long addendum spur gears / H. Mizutani, Y. Isikawa // VDI - Berichte. - 1996, № 1230. p. 83-95.

13. Naruse C. Limiting Loads for Scoring and Frictional Loss of Hypoid Gear / C. Naruse, S. Haizuka, R. Nemoto, T. Umezu // Bulletin of JSME. July, 1986. - Vol. 29, № 253. 
p. 2271-2280.

14. Yada T. Review of gear efficiency equation and force treatment / JSME International journal. - 1997. - Series C, Vol. 40. - P. 1- 8.

15. Benedict G. H. Instantaneous coefficients of gear tooth friction. / G.H. Benedict, B.W. Kelley. // Tribology transactions. - 1961. - Vol. 4. - P. 594.

16. Benedict G. H. Instantaneous coefficients of gear tooth friction. / G.H. Benedict, B.W. Kelley. // Transactions of ASLE, ASLE Lubrication conference. - October, 1960. - P. 57-70.

17. Drozdov Y. N. Friction and scoring under the conditions of simultaneous roiling and sliding of bodies. / Y. N. Drozdov. Y. A. Gavrikov // Wear. -1967.-P. 291-302.

18. Höhn B.R. Influence on no-load gear losses / B.R. Höhn. K. Michaelis, H.P. Otto // Processing of the ecotrib conference. -2011,-Vol. 2. - P. 639-644.

19. Ku P.M. Frictional and thermal behaviours of sliding-rolling concentrated contacts / P.M. Ku, H.E. Staph, H.J. Carper // Journal of Lubiication Technology. - 1978. - Vol.100. - P. 121-128.

20. Plint M.A. Traction in elastohydrodynamic contacts / M.A. Plint, F.I.E. Mech // Proc Instn. Mech. Engrs. - 1967-68. - Vol. 182. Pt. 1. № 14.

21. O'Donoghue J.P. Friction and temperature in rolling sliding contacts / J.P. O'Donoghue, A. Cameron // ASLE Transactions. - 1966. - №9. - P. 1639-1664.

22. Henkyn M.D. Voprost zaedanyia zubchatikh koles / M.D. Henkyn, N.F. Kuzmyn, Yu.A. Mysharyn. - M.: Yzdano AN SSSR, 1959. - S. 1-147.

23. Misharin Y.A. Influence of the friction condition on the magnitude of the friction coefficient in the case of rollers with sliding / Proc. Int. conf. on gearing. 1958, Inst, Mech. Eng., London, p. 159-164.

24. Crook A.W. A theoretical discussion of friction and the temperatures in the oil film. // Philosophical Transactions of the Royal Society of London. - 1961. - Ser. A. Vol. 254. - P. 237-258.

25. Blok H. Hydrodynamics effects on friction in rolling with slippage. // Biolwelle Joseph B. Rolling contact phenomena. - Amsterdam: Elsevier. 1962.

26. Kelley B.W. Lubrication of involute gearing. / B.W. Kelley, A.J. Lemanski // Proc. Inst. Mech. Engrs. - 1967-1968. - Vol. 182. - P. 173-184.

27. Bercsey T. Modeling of the contact and tribological relations of spatial gear pairs. / T. Bercsey, P. Horak // VDI - Berichte. - 2002. - № 1665 - P.91-105.

28. Hirano F. Effect of angle between direction of sliding and line of contact on friction and wear of a roller. / F. Hirano, T. Ueno, S. Asanabe // Lubrication engineering. - 1964. - P. 57-64.

29. Tan J. Effects of sliding/rolling contact un worm gear lubrication / J. Tan, T. Yamada, N. Hattori // The JSME international conference on motion and power transmissions. Hiroshima, Japan, 1991. - P. 1123-1127.

30. Denny C.M. Mesh friction in gearing. // AGMA Fall Technical Meeting. 1998.98FTM2.

31. Pedrero J.I. Determination of the efficiency of cylindrical gear sets / J.I. Pedrcro // 4th World congress on gearing and power transmission, Paris, France. March, 1999.

32. Anderson N. E. Efficiency of non-standard and high contact ratio involute spur gears. / N. E. Anderson, S. H Loewenthal // Journal of mechanisms, transmissions and automation in design. - 1986. - Vol. 108. -P. 119-126.

33. Barnes J.P. Non-dimensional characterization of gear geometry. Mesh loss and windage. Fall AGMA/MSME Meeting, San Diego, CA. - 1997. 97FTM11, p. 12.

34. Heingartner P. Determining power losses in the helical gear mesh: Case Study / P Heingartner, D. Mba // DETC'3: Chicago, Illinois, 2003.

35. Wu S. A friction model of purtial-EHL contacts and its application to power loss in spur gears / S. Wu, H. Cheng // Tribology transactions. -1991 - Vol. 34, №3. - P.398-407.

36. Mihalidis A. Predilion of the friction coefficient of spur gear pairs. A. Mihalidis, V. Bakola, K. Panagiotidis, N. Dmakos \VDI -Beridte. №1665 - P. 705-719.

37. Wang Y. Transient thermal elastohydrodynumic lubrication analisis of an involute spur gear /

Y. Wang. H. Li. J. Tong, P. Yang / Tribology International. 2004. - Vol. 37. - P. 773-782.

38. Simon V. Load capacity and efficiency of spur gears in regard to thermo-end lubrication / V. 
Simon // International symposium on gearing and power transmissions, Tokyo, Japan, 1981.

39. Larsson $\mathrm{R}$ Transient non-Newtonian elastohydrodynamic lubrication analysis of an involute spur gears / R. Larsson // Wear. - 1997/ - Vol. 207. - P. 67-73.

40. Dowson D. A theory of involute gear lubrication. / D. Dowson, G.R. Higginson // Proceeding of a symposium organized by the mechanical tests of lubricants panel of the institute of petroleum. Gear lubrication. Elsevier. London. - 1964. - P. 8-15.

41. Adkins R. W. Lubrication phenomena in spur gears: capacity, film thickness variation and efficiency. / R. W. Adkins, E. I. Radzimovsky // Journal of basic engineering. - 1964. - P. 1-9.

42. Chittenden R. J- A Theoretical analysis of the isothermal elastohydrodynamic lubricant of concentrated contacts. / R. J. Chittenden. D. Dowson. J. P. Dunn, C. M. Taylor. // Proc, of the Royal Society of London. - 1985. - Ser. A. - Vol. 397 - P. 271-294.

43. Haizuka S., Naruse C., Yamanaka T. Study of influence of helix angle on friction characteristics of helical gears. / S. Haizuka, C. Naruse, T. Yamanaka // Tribology transactions. - 1999 - Vol. 42. № 3. - P. 370-380.

44. Buckingham E. Efficiencies of gears. Analytical mechanics of gears. Mew York: Dover, 1963. - P. 395-425.

45. Coleman W- A scoring formula for bevel and hypoid gear teeth. // Transaction of the ASME Journal of lubrication technology. - 1967. -Ser.F87-2.-P.114-126.

46. Jia Y. Multilevel solution of elastohydrodynamically lubricated hypoid gears. / Y. Jia, X. Guo. C. Chen, J. Shao // International gearing Conference. University of Newcastle upon Tyne. UK. - 1904. - p. 329-334.

Стаття надійшла до редакції 30.11.2020.

Башта Олександр Васильович - к.т.н., доцент, доцент кафедри машинознавства, стандартизації та сертифікації Національного авіаційного університету, м. Київ, Україна, nau12@ukr.net.

Носко Павло Леонідович - д.т.н., професор, професор кафедри машинознавства, стандартизації та сертифікації Національного авіаційного університету, м. Київ, Україна, тел. 406-78-42.

Радько Олег Віталійович - к.т.н., доцент, доцент кафедри авіації Національний університет оборони України імені І. Черняховського, м. Київ, Україна.

Герасимова Ольга Вячеславівна - Національний авіаційний університет, м. Київ, Україна, тел. 406-78-42, nau12@ukr.net.

Башта Алла Олексіївна - к.т.н., доцент, Національний університет харчових технологій, доцент кафедри Технології оздоровчих продуктів, м. Київ, Україна. 
O. BASHTA, P. NOSKO, O.RADKO, O.GERASIMOVA, A. BASHTA

\section{INVESTIGATION OF POWER LOSSES DUE TO SLIDING AND ROLLING FRICTION IN GEARS. REVIEW}

The analysis of researches concerning power losses owing to friction in gear pairs is carried out. It is established that the determination of the efficiency of gears uses three different approaches: direct measurement of power losses of real gears, contact-dynamic modeling based on real physical processes, analytical modeling of friction processes in gears based on empirical information about friction obtained on special friction machines. It is established that the values of friction forces between the connected teeth are largely determined by hydrodynamic (elastohydrodynamic) phenomena in the contact zone. The analysis of works showed that the contact between the surfaces of the connected teeth is characterized by large deformations, high contact stresses and the presence of a film of lubricant, which in turn is characterized by its viscosity. To date, the effect of sliding in the direction of the line of contact of the teeth on the coefficient of friction and lubrication conditions are insufficiently studied. There are two groups of semi-analytical models in the published works. The first group of authors investigated the efficiency of spur gears, assuming that the coefficient of friction is constant along the entire contact surface of the friction surfaces in any position of the gears during their rotation. However, they have a number of significant disadvantages. It is assumed that the coefficient of friction is constant and known in advance for each point of contact of a pair of teeth. However, experimental data for two friction disks show that in the conditions of the combined sliding / rolling contact the coefficient of friction is not constant and is influenced by many parameters. Also, these models were limited to spur gears and did not take into account many factors that make a significant complication of the models. The second group of semi-analytical models can be considered as an improvement of the models of the first group with a constant coefficient of friction. To date, the models of the second group are potentially more accurate than the models of the first group. The accuracy of the description using these models is limited by the accuracy of the empirical formulas used in them. These empirical formulas are not general in nature and are often a function of certain types of lubricants, operating temperatures, speed and load limits, and surface cleanliness of test specimens, which may differ from similar parameters of real gears.

Key words: power losses, efficiency, contact-hydrodynamic theory, semi-analytical models, friction coefficient.

\section{References}

1. Reuleaux F. Friction in tooth gearing / Transactions of the ASME. - 1886. - Vol. VIII. - P. 45-85.

2. Martin K.F. A review of friction predictions in gear teeth / Wear. - 1978. - № 49. - P. 201-238.

3. Petrusevych A.Y. Kontaktnaia prochnost detalei mashyn /- M.: Mashynostroenye, 1970. - $64 \mathrm{~s}$.

4. Petrusevych A.Y. Uproshchennыi metod reshenyia kontaktno-hydrodynamycheskykh zadach / Mashynovedenye. -1971.-№6.-S. 72-76.

5. Kodnyr D.H. Kontaktna hydrodynamyka smazky detalei mashyn / - M.: Mashynostroenye, 1976. - $304 \mathrm{~s}$.

6. Kudriavtsev V.N. Raschet y proektyrovanye zubchatukh reduktorov: Spravochnyk / V.N. Kudriavtsev, Y. S. Kuzmyn, A.L. Fylypenkov; Pod obshch, red. V.N. Kudriavtseva. SPb.: Polytekhnyka, 1993. - 448 s.

7. Benedict G.H. Instantaneous coefficients of gear tooth friction. / G.H. Benedict, B.W. Kelley // Tribology transactions. - 1961. - Vol. 4. - P. 594.

8. Gohar R. Oil film thickness and rolling friction in elastohydrodynamic point contact/ J. Lubrication technology. - 1971. - №93 (3)-P.371.

9. Changenet C. Power losses and heat exchange in reduction gears: numerical and 
experimental results. / C. Changenet, M. Pasquier. // VDI -Berichte. - 2002. -№ 1665. - P. 603-613.

10. Hori K. Determination of the tooth surface friction coefficient of a pair of mating gears based on the distribution along the tooth profile precisely measured with the gravity pendulum method / K. Hori, I. Hayashi. N Iwatsuki // Proceedings of DETC'00/PTG-14371. Baltimore. Maryland. 10-13 September. 2000.

11. Ikejo K. Power loss of spur gear drive lubricated with traction oil / K. Ikcjo, K. Nagamura // DETC'03/PTG, Chicago, Illinois, 2003.

12. Mizutani H. Power loss of long addendum spur gears / H. Mizutani, Y. Isikawa // VDI - Berichte. - 1996, № 1230. p. 83-95.

13. Naruse C. Limiting Loads for Scoring and Frictional Loss of Hypoid Gear / C. Naruse, S. Haizuka, R. Nemoto, T. Umezu // Bulletin of JSME. July, 1986. - Vol. 29, № 253. p. 2271-2280.

14. Yada T. Review of gear efficiency equation and force treatment / JSME International journal. - 1997. - Series C, Vol. 40. - P. 1- 8.

15. Benedict G. H. Instantaneous coefficients of gear tooth friction. / G.H. Benedict, B.W. Kelley. // Tribology transactions. - 1961. - Vol. 4. - P. 594.

16. Benedict G. H. Instantaneous coefficients of gear tooth friction. / G.H. Benedict, B.W. Kelley. // Transactions of ASLE, ASLE Lubrication conference. - October, 1960. - P. 57-70.

17. Drozdov Y. N. Friction and scoring under the conditions of simultaneous roiling and sliding of bodies. / Y. N. Drozdov. Y. A. Gavrikov // Wear. -1967.-P. 291-302.

18. Höhn B.R. Influence on no-load gear losses / B.R. Höhn. K. Michaelis, H.P. Otto // Processing of the ecotrib conference. -2011,-Vol. 2. - P. 639-644.

19. Ku P.M. Frictional and thermal behaviours of sliding-rolling concentrated contacts / P.M. Ku, H.E. Staph, H.J. Carper // Journal of Lubiication Technology. - 1978. - Vol.100. - P. 121-128.

20. Plint M.A. Traction in elastohydrodynamic contacts / M.A. Plint, F.I.E. Mech // Proc Instn. Mech. Engrs. - 1967-68. - Vol. 182. Pt. 1. № 14.

21. O'Donoghue J.P. Friction and temperature in rolling sliding contacts / J.P. O'Donoghue, A. Cameron // ASLE Transactions. - 1966. - №9. - P. 1639-1664.

22. Henkyn M.D. Voprost zaedanyia zubchatikh koles / M.D. Henkyn, N.F. Kuzmyn, Yu.A. Mysharyn. - M.: Yzdano AN SSSR, 1959. - S. 1-147.

23. Misharin Y.A. Influence of the friction condition on the magnitude of the friction coefficient in the case of rollers with sliding / Proc. Int. conf. on gearing. 1958, Inst, Mech. Eng., London, p. 159-164.

24. Crook A.W. A theoretical discussion of friction and the temperatures in the oil film. // Philosophical Transactions of the Royal Society of London. - 1961. - Ser. A. Vol. 254. - P. 237-258.

25. Blok H. Hydrodynamics effects on friction in rolling with slippage. // Biolwelle Joseph B. Rolling contact phenomena. - Amsterdam: Elsevier. 1962.

26. Kelley B.W. Lubrication of involute gearing. / B.W. Kelley, A.J. Lemanski // Proc. Inst. Mech. Engrs. - 1967-1968. - Vol. 182. - P. 173-184.

27. Bercsey T. Modeling of the contact and tribological relations of spatial gear pairs. / T. Bercsey, P. Horak // VDI - Berichte. - 2002. - № 1665 - P.91-105.

28. Hirano F. Effect of angle between direction of sliding and line of contact on friction and wear of a roller. / F. Hirano, T. Ueno, S. Asanabe // Lubrication engineering. - 1964. - P. 57-64.

29. Tan J. Effects of sliding/rolling contact un worm gear lubrication / J. Tan, T. Yamada, $\mathrm{N}$. Hattori // The JSME international conference on motion and power transmissions. Hiroshima, Japan, 1991. - P. 1123-1127.

30. Denny C.M. Mesh friction in gearing. // AGMA Fall Technical Meeting. 1998.98FTM2.

31. Pedrero J.I. Determination of the efficiency of cylindrical gear sets / J.I. Pedrcro // 4th World congress on gearing and power transmission, Paris, France. March, 1999.

32. Anderson N. E. Efficiency of non-standard and high contact ratio involute spur gears. / N. E. Anderson, S. H Loewenthal // Journal of mechanisms, transmissions and automation in design. - 1986. - Vol. 108. -P. 119-126. 
33. Barnes J.P. Non-dimensional characterization of gear geometry. Mesh loss and windage. Fall AGMA/MSME Meeting, San Diego, CA. - 1997. 97FTM11, p. 12.

34. Heingartner P. Determining power losses in the helical gear mesh: Case Study / P Heingartner, D. Mba // DETC'3: Chicago, Illinois, 2003.

35. Wu S. A friction model of purtial-EHL contacts and its application to power loss in spur gears / S. Wu, H. Cheng // Tribology transactions. -1991 - Vol. 34, №3. - P.398-407.

36. Mihalidis A. Predilion of the friction coefficient of spur gear pairs. A. Mihalidis, V. Bakola, K. Panagiotidis, N. Dmakos \VDI -Beridte. №1665 - P. 705-719.

37. Wang Y. Transient thermal elastohydrodynumic lubrication analisis of an involute spur gear / Y. Wang. H. Li. J. Tong, P. Yang / Tribology International. 2004. - Vol. 37. - P. 773-782.

38. Simon V. Load capacity and efficiency of spur gears in regard to thermo-end lubrication / V. Simon // International symposium on gearing and power transmissions, Tokyo, Japan, 1981.

39. Larsson $\mathrm{R}$ Transient non-Newtonian elastohydrodynamic lubrication analysis of an involute spur gears / R. Larsson // Wear. - 1997/ - Vol. 207. - P. 67-73.

40. Dowson D. A theory of involute gear lubrication. / D. Dowson, G.R. Higginson // Proceeding of a symposium organized by the mechanical tests of lubricants panel of the institute of petroleum. Gear lubrication. Elsevier. London. - 1964. - P. 8-15.

41. Adkins R. W. Lubrication phenomena in spur gears: capacity, film thickness variation and efficiency. / R. W. Adkins, E. I. Radzimovsky // Journal of basic engineering. - 1964. - P. 1-9.

42. Chittenden R. J- A Theoretical analysis of the isothermal elastohydrodynamic lubricant of concentrated contacts. / R. J. Chittenden. D. Dowson. J. P. Dunn, C. M. Taylor. // Proc, of the Royal Society of London. - 1985. - Ser. A. - Vol. 397 - P. 271-294.

43. Haizuka S., Naruse C., Yamanaka T. Study of influence of helix angle on friction characteristics of helical gears. / S. Haizuka, C. Naruse, T. Yamanaka // Tribology transactions. - 1999 - Vol. 42. № 3. - P. 370-380.

44. Buckingham E. Efficiencies of gears. Analytical mechanics of gears. Mew York: Dover, 1963. - P. 395-425.

45. Coleman W- A scoring formula for bevel and hypoid gear teeth. // Transaction of the ASME Journal of lubrication technology. - 1967. -Ser.F87-2.-P.114-126.

46. Jia Y. Multilevel solution of elastohydrodynamically lubricated hypoid gears. / Y. Jia, X. Guo. C. Chen, J. Shao // International gearing Conference. University of Newcastle upon Tyne. UK. - 1904. - p. 329-334. 